of the main bronchus and W. K. Pallister describes a new endobronchial tube for the left lung. The value of the surgical contributions is greatly enhanced by the two articles by Sir Russell C. Brock, one of which is his Bradshaw Lecture on the present position of cardiac surgery (with its tribute to the work of Sir Charles Ballance and the part he played in the death of the superstition that the heart is untouchable), and the other is on direct operations for the correction of Fallot's tetralogy. Dr. J. G. Scadding contributes an opening article on the principles of definition in medicine, with special reference to chronic bronchitis and emphysema.

The bibliographies of all these articles are valuable, but would be more so if the titles of the papers quoted were given. The volume concludes with a list of papers published by members of the staff of the Brompton Hospital between August 1958 and July 1959 and with author and subject indexes to volumes $1-28$.

Geoferey LAPage

\section{ELEMENTS OF PHYSICAL CHEMISTRY}

\section{Elements of Physical Chemistry}

By Samuel Glasstone and Prof. David Lewis. Pp. $\mathrm{v}+758$. (London: Macmillan and Co., Ltd., 1960.) $60 s$. net.

CTUDENTS and teachers of physical chemistry $\$$ will need no introduction to the Elements of Physical Chemistry by Glasstone and Lewis, the second edition of the book first produced by Glasstone in 1945. The major change in the new edition is a re-ordering of the chapters, so that after an initial outline of the properties of gases the reader is led through the realms of thermodynamics. This has the advantage of enabling such phenomena as vaporization of liquids and solids to be treated thermodynamically when first met, rather than phenomenologically as in the earlier edition. The molecular nature of matter is introduced in the billiard-ball approximation, in the chapter on the gaseous state via the kinetic theory, the more intimate details of the structure of atoms and molecules, and the direct evidence for their existence being left until a later stage. From this point onwards the book follows much the same well-established lines as the earlier edition. However, a new chapter on nuclear chemistry has been included. New material has been incorporated in all the chapters, to bring the book into line with contemporary developments.

The increased attention given to two of the basic theories of physical chemistry, namely wave mech. anics and statistical mechanics, is welcome, although I feel that the section on the Schrödinger equation could well have been extended to indicate the way in which eigen values fall naturally out of the assumptions of the theory.

The book is written in such a way as to be readily understood by the student commencing the subject; moreover, the references given at the ends of the chapters should stimulate him to further reading of the subject. These references have been extended to include well-known review journals, as well as those to the Journal of Chemical Education, which were the sole source of additional information in the first edition.

To understand physicel chemistry completely the student needs to acquire the facility to manipulate the results of experimental observation as well as the basic concepts. Development along these lines is encouraged by a new selection of problems at the end of each chapter, designed to set the reader thinking, and to develop his ability to interpret experimental results within the framework of physico-chemical theory.

The book is very well and attractively produced, and the figures have been well chosen to bring home to the reader the points in question. There is no doubt, in my mind, that the part played in the teaching of physical chemistry by the first edition will be more than adequately filled by the second.

A. MACCOII

\section{BRITISH FOOD ANALYSIS}

The Composition of Foods

By Dr. R. A. McCance and Dr. E. M. Widdowson : Privy Council. Medical Research Council Special Report Series, No. 297. (London : H. M. Stationery Office.) 1960. (Third revised edition of Special Report No. 235.) Pp. viii +252. 30s. net.

THIS book of tables, giving the composition of a comprehensive selection of foods commonly eaten in Britain, is the third edition of the Medical Research Council Special Report Series No. 235, originally published in 1939. In 1942 the first edition was revised, the revisions including a change in the method of calculating the calorie value of carbohydrate, and the addition of 'National' 85 per cent flour and bread to the foods anelysed. The second edition, published in 1946, included some other foods introduced into the nation's diet as a result of the Second World War. Both editions are well known to nutrition workers. The tables were the result of analytical work carried out under the direction of Prof. McCance since 1925. They showed the important organic and mineral constituents, with the exception of vitamins, of most of the foods in cornmon use in Great Britain. Foods were analysed not only in the raw state but also as prepared for the table. The composition of many cooked dishes was given.

The basis of the third and latest edition remains the same. However, some foods no longer generally consumed have been omitted, and some of the many new proprietary foods which have appeared on the market since the War have been added. More than 100 new foods, including cereal preparations, soft drinks, sweets and alcoholic beverages, figure in this edition. Changes in the composition of various proprietary foods have made it necessary to revise values previously given.

Important and useful additions are two new tables showing the vitamin and amino-acid content of foods. The vitamin values are derived from assays made by other workers, while the amino-acid figures are a combination of the authors' own results and those of other workers.

In its revised form this well-known work will no doubt continue to serve nutrition workers and dietitians, retaining an honoured place among various other food composition compilations, national 